\title{
The Environmental Impact of Pig Farming
}

\author{
Gennady Samarin ${ }^{1}$, Alexey Vasilyev ${ }^{1}$, Dmitry Tikhomirov${ }^{1}$, Dmitry Normov ${ }^{2}$, \\ Alexey Pavlov $^{3}$, Irina Kokunova ${ }^{3}$, Margarita Solovieva ${ }^{3}$, and Leonid Dvoretckii ${ }^{4}$ \\ ${ }^{1}$ Federal Scientific Agroengineer Center VIM, 5, 1-y Institutsky proezd, Moscow, 109428, Russia \\ ${ }^{2}$ Kuban State Agrarian University, 13, Azovskaya street, Krasnodar, 350012, Russia \\ ${ }^{3}$ Velikie Luki State Agricultural Academy, 2, Lenin Ave., Velikie Luki, Pskov region, 182112, Russia \\ ${ }^{4}$ The Herzen State Pedagogical University of Russia, 48, Moika Emb., St. Petersburg, 191186, \\ Russia
}

ORCID:

Gennady Samarin: http://orcid.org/0000-0002-4972-8647

\section{Abstract}

This study aimed to develop a methodology to evaluate the protection of animals and people from the harmful effects of the farm's microclimate and environment, taking into consideration the energy, economic and environmental indicators. To achieve this goal, the following were determined for 2019 for the eight countries which are the world leaders in the field of pig farming: the volumes of carbon dioxide pollution, ammonia,

Corresponding Author: Gennady Samarin samaringn@yandex.ru

Published: 5 April 2021

Publishing services provided by Knowledge E

(c) Gennady Samarin et al. This article is distributed under the terms of the Creative Commons Attribution License, which permits unrestricted use and redistribution provided that the original author and source are credited.

Selection and Peer-review under the responsibility of the DonAgro Conference Committee. dust and manure, and the analytical dependencies between the feed consumption, pig productivity and the concentration of ammonia inside the farm. The weight gain of pigs reduced by $15 \%$ with an increase in the concentration of ammonia in the internal air of livestock houses to $20 \mathrm{mg} / \mathrm{m}^{3}$, but the feed wastage increased by $12 \%$. Mathematical models were developed to estimate the relationships between the feed consumption, pig productivity and the concentration of harmful gas (ammonia) which is one of the main parameters of the microclimate. The results will be used in making technical and technological decisions in the field of microclimate, cleaning and disposal of farm manure.

Keywords: pig, farming, ecology, environment.

\section{Introduction}

With the extensive development of pig farming, which is characterized by the predominance of small and medium-sized farms, the ecological system is disrupted for a short time and usually quickly restored. And, on the contrary, with intensive development, which is characterized by large pig farms and complexes, the air, soil, surface and groundwater are maximally polluted. In modern conditions, most of the leading countries in the field of pig farming (see Table 1) have chosen an intensive development path due to the objective reasons. The data presented in Table 1 based on the data from the official websites of the following organizations: Food and Agriculture Organization of the 
United Nations (FAO), United States Department of Agriculture (USDA), the Ministry of Agriculture of the Russian Federation (RF MA), the Unified Interdepartmental Statistical Information System of the Russian Federation (RF UISIS).

Farms are powerful sources of environmental pollution. Annually, billions of cubic meters of water vapour, carbon dioxide, ammonia, hundreds of thousands of cubic meters of hydrogen sulfide, tens of thousands of tons of dust, and pathogenic microflora are released from the premises of livestock farms in Russia [1, 2].

According to Belarusian scientists, the Sozh pig complex in the Gomel region for 108 thousand pigs emits $56 \mathrm{~kg}$ of ammonia and $15-20 \mathrm{~kg}$ of dust into the atmosphere in 1 hour, and unpleasant odours spread to a distance of $5 \mathrm{~km}$ [3].

Modern technologies for housing animals specify high requirements to the microclimate in livestock premises. According to scientists, livestock specialists and technologists, the productivity of animals is $50 . . .60 \%$ determined by feed and water consumption, $15 \ldots 20 \%$ - by care and $10 \ldots 30 \%$ - by the microclimate in the livestock premises [1, 4-8]. Deviation of microclimate parameters from the set of optimal values leads to a reduction of live weight gain by $20 . . .35 \%$, increasing the waste of young stock to $5 . . .40 \%$, consumption of additional quantities of feed, reducing the service life of equipment, machinery and buildings, and leads to a negative impact on staff, reducing the resistance of livestock to diseases [2, 9-12].

Currently, as opposed to other scientists and specialists, we distinguish more than 10 environmental parameters that affect the livestock inside the farm: temperature, humidity and airspeed, atmospheric pressure; concentration of harmful gases (carbon dioxide, ammonia, hydrogen sulfide); concentration of dust and microbial bodies; production noise, illumination and electromagnetic fields [1, 2, 13, 14].

This paper considers only one parameter of the environment inside the farm (microclimate) - the concentration of ammonia.

Ammonia is poisonous. It strongly irritates the mucous membranes. Acute ammonia poisoning causes damage to the eyes and respiratory tract, shortness of breath, and inflammation of the lungs. [15]

The source of ammonia in the air of premises for livestock is the decomposition of various substances containing nitrogen (urine, faeces). Especially a lot of ammonia occurs in stables, as well as in pigsties and calf premises in the case of floor permeability, absence or poor operation of sewerage and ventilation.

Ammonia is highly soluble in water, so it is primarily absorbed by the mucous membranes of the nasopharynx, upper respiratory tract and conjunctiva of the eyes, 
TABLE 1: Dynamics of the livestock of pigs, million heads

\begin{tabular}{|c|c|c|c|c|c|c|c|c|c|}
\hline $\begin{array}{l}\text { No. The place } \\
\text { occupied by a } \\
\text { country/region } \\
\text { in the } \\
\text { world/country }\end{array}$ & 1995 & 2000 & 2005 & 2010 & 2015 & 2017 & 2018 & 2019 & $\begin{array}{c}2019 \text {, in } \\
\% \text { by } \\
2000\end{array}$ \\
\hline 1. China & 441.7 & 416.3 & 433.2 & 464.6 & 451.1 & 433.3 & 428.2 & 310.4 & 74.56 \\
\hline 2. USA & 58.2 & 59.1 & 61.5 & 64.9 & 68.9 & 73.1 & 75.6 & 77.3 & 130.80 \\
\hline 3. Spain & 18.1 & 22.1 & 24.9 & 25.7 & 28.4 & 30.0 & 30.8 & 31.2 & 141.18 \\
\hline 4. Germany & 23.7 & 25.8 & 27.0 & 26.9 & 27.7 & 27.6 & 26.4 & 26.1 & 101.16 \\
\hline 6. Russia & 22.6 & 15.7 & 13.8 & 17.2 & 21.5 & 23.1 & 23.7 & 25.2 & 160.51 \\
\hline Canada & 11.5 & 13.6 & 15.1 & 12.7 & 13.6 & 14.2 & 14.0 & 13.9 & 102.21 \\
\hline France & 14.5 & 15.2 & 15.1 & 14.3 & 13.3 & 13.4 & 13.7 & 13.5 & 88.82 \\
\hline Poland & 20.3 & 17.0 & 18.7 & 14.8 & 10.6 & 11.9 & 11.0 & 11.2 & 65.88 \\
\hline \multicolumn{10}{|l|}{$\begin{array}{l}\text { Regions of } \\
\text { Russia: }\end{array}$} \\
\hline $\begin{array}{l}\text { 4. Pskov } \\
\text { region }\end{array}$ & 0.14 & 0.084 & 0.064 & 0.074 & 0.65 & 1.02 & 1.15 & 1.3 & 1547.6 \\
\hline $\begin{array}{l}\text { 16. Krasnodar } \\
\text { krai }\end{array}$ & 1.75 & 1.53 & 1.3 & 1.00 & 0.43 & 0.41 & 0.53 & 0.63 & 41.18 \\
\hline $\begin{array}{l}\text { Moscow } \\
\text { oblast }\end{array}$ & 0.47 & 0.18 & 0.143 & 0.3 & 0.3 & 0.32 & 0.33 & 0.33 & 183.33 \\
\hline
\end{tabular}

Information on some of the largest pork producers (5. Brazil, 7. Vietnam, Mexico, Korea) is not presented in the table.

causing severe irritation to them. Coughing, sneezing, eye tearing are followed by inflammation of the mucous membranes of the nose, larynx, trachea, bronchi and conjunctiva. With a high content of ammonia $\left(1000 . . .3000 \mathrm{mg} / \mathrm{m}^{3}\right)$ in the inhaled air, animals have spasms of the glottis, tracheal and bronchial muscles, death occurs from pulmonary oedema or respiratory paralysis [16].

When ammonia passes the blood through the lungs (the alveolar epithelium can pass ammonia), it turns the haemoglobin of red blood cells into alkaline hematin, which reduces the amount of haemoglobin and the number of red blood cells; anaemia is observed, and blood clotting increases [17].

According to experts, in the case of prolonged inhalation of air containing ammonia (0.33...0.97\%), the amount of haemoglobin, blood alkaline reserve, gas exchange, digestibility of nutrients (protein, fat, fibre) reduce in livestock and the productivity decreases. The intake of large amounts of ammonia into the blood causes a strong excitation of the Central nervous system of the brain, spinal cord and especially the medulla oblongata, convulsions of the entire body, and in the intervals between them, there is a comatose state, an increase in blood pressure, finally, paralysis of the respiratory centre and death. The continuous and long-term effect on livestock of ammonia 
at a concentration of $0.15 \%$ or more worsens the general condition, food is poorly digested, daily weight gains fall, and the number of respiratory diseases increases. At higher concentrations, ammonia causes acute poisoning, accompanied by rapid death of livestock [1].

The symptoms of chronic human poisoning are the following: in the workers of chemical plants (at the concentration of $0.5 \ldots 24 \mathrm{mg} / \mathrm{m}^{3}$ ), it was observed the cases of anosmia or hyposmia, neurasthenia, decreased bioelectric activity of the brain, increased activity of glutamic pyruvate transaminase and decreased level of vitamin $C$ in the blood, decreased excretion of urea, increased need for vitamin B1. The incidence of upper respiratory tract catarrh, angina, tonsillitis is increased. It was registered the changes in fat and protein metabolism and the increased incidence of catarrhal diseases of the upper respiratory tract in adolescents undergoing practical training at the factory, even with a 3-hour working day and the concentrations that do not exceed the maximum allowed [1].

Based on the collected and processed material, the dependences of the influence of the concentration of ammonia in the internal air of the farm on the productivity of pigs and feed consumption are investigated, and they are shown in Figure 1.

\section{Methods}

Based on some research [14, 18-21], it was established that the average specific indicators of pollution and waste by pigs have the following values: carbon dioxide $\mathrm{CO}_{2}$ - $0.12078 \mathrm{~kg} / \mathrm{h} / \mathrm{head}$; ammonia $\mathrm{NH}_{3}-0.0007 \mathrm{~kg} / \mathrm{h} / \mathrm{head}$; dust - $0.0002 \mathrm{~kg} / \mathrm{h} / \mathrm{head}$; manure $-6.6 \mathrm{~kg} / \mathrm{day} / \mathrm{head}$.

Using these values, it was calculated the approximate volumes of pig pollution during the period of 2019 for the countries and regions of the Russian Federation, which are presented in Table 1. These results are presented in Table 2.

The development of methodological techniques for calculating, designing and solving a complex problem with zooengineering, engineering and technical, sanitary and hygienic, environmental aspects was based and carried out using the provisions, laws and methods of probability theory, mathematical modelling, statistics, and optimization.

To find the optimal technologies for forming microclimate parameters inside the farm, the results of scientific research in this area were explored and summarized, based on which the mathematical models were developed to investigate analytical dependencies between feed consumption, pig productivity and ammonia concentration [22-28]. 


\section{Results}

TABLE 2: Volumes of pig farming pollution in 2019 for some countries and regions of the Russian Federation

\begin{tabular}{|c|c|c|c|c|c|}
\hline \multirow{2}{*}{$\begin{array}{l}\text { No. The place } \\
\text { occupied by a } \\
\text { country/region } \\
\text { in the } \\
\text { world/country }\end{array}$} & \multirow{2}{*}{$\begin{array}{l}\text { The number } \\
\text { of pigs, } \\
\text { million } \\
\text { heads }\end{array}$} & \multicolumn{4}{|c|}{ The amount of pollution, Gkg/year } \\
\hline & & $\begin{array}{c}\text { Carbon } \\
\text { dioxide, } \mathrm{CO}_{2}\end{array}$ & $\begin{array}{c}\text { Ammonia } \\
\mathrm{NH}_{3}\end{array}$ & Dust & Manure \\
\hline 1. China & 310.4 & 328.41 & 1.9034 & 0.5438 & 747.75 \\
\hline 2. USA & 77.3 & 81.79 & 0.4740 & 0.1354 & 186.22 \\
\hline 3. Spain & 31.2 & 33.01 & 0.1913 & 0.0547 & 75.16 \\
\hline 4. Germany & 26.1 & 27.61 & 0.1600 & 0.0457 & 62.87 \\
\hline 6. Russia & 25.2 & 26.66 & 0.1545 & 0.0442 & 60.71 \\
\hline Canada & 13.9 & 14.71 & 0.0852 & 0.0244 & 33.49 \\
\hline France & 13.5 & 14.28 & 0.0828 & 0.0237 & 32.52 \\
\hline Poland & 11.2 & 11.85 & 0.0687 & 0.0196 & 26.98 \\
\hline \multicolumn{6}{|l|}{$\begin{array}{l}\text { Regions of } \\
\text { Russia: }\end{array}$} \\
\hline 4. Pskov region & 1.3 & 1.38 & 0.0080 & 0.0023 & 3.13 \\
\hline $\begin{array}{l}\text { 16. Krasnodar } \\
\text { krai }\end{array}$ & 0.63 & 0.67 & 0.0039 & 0.0011 & 1.52 \\
\hline Moscow oblast & 0.33 & 0.35 & 0.0020 & 0.0006 & 0.79 \\
\hline
\end{tabular}

Important: $1 \mathrm{Gkg}=1 \times 10^{12} \mathrm{~kg}=1 \times 10^{9} \mathrm{t}$

Based on the collected and processed material, the dependences of the influence of the concentration of ammonia in the internal air of the farm on the productivity of pigs and feed consumption are investigated, and they are presented in Figure 1.

In Figure 1, it can be noticed that when the concentration of ammonia in the internal air of the livestock premises increases to $20 \mathrm{mg} / \mathrm{m}^{3}$, the weight gain of pigs decreases by $15 \%$, and the overconsumption of feed increases by $12 \%$.

Based on the dependencies of Figure 1, it was calculated the regression equations $(1,2)$ for the effect of the concentration of ammonia in the internal air of the farm $\mu_{17}$ $\left(\mathrm{NH}_{3}\right), \mathrm{mg} / \mathrm{m}^{3}$ on the weight gain of pigs $\mathrm{Cwg}$ (the coefficient of weight gain), \% and the feed consumption Cfc (the coefficient of feed consumption), \%

$$
\begin{gathered}
C w g=-9.7 \cdot 10^{-6} \cdot\left(\mu_{17}\right)^{3}+0.00284 .\left(\mu_{17}\right)^{2}-0.88675 \cdot \mu_{17}+101.4292, a t 0 \leq \mu_{17} \leq 150 \\
C f c=0.56 \cdot \mu_{17}+100.2 a t 0 \leq \mu_{17} \leq 20
\end{gathered}
$$




\section{Discussion}

To make the most complete and comprehensive assessment of technological decisions in the field of microclimate, cleaning and utilization of farm manure, experts are often suggested using four groups of indicators: functional and technological; structural and layout; operational and energy; economic.

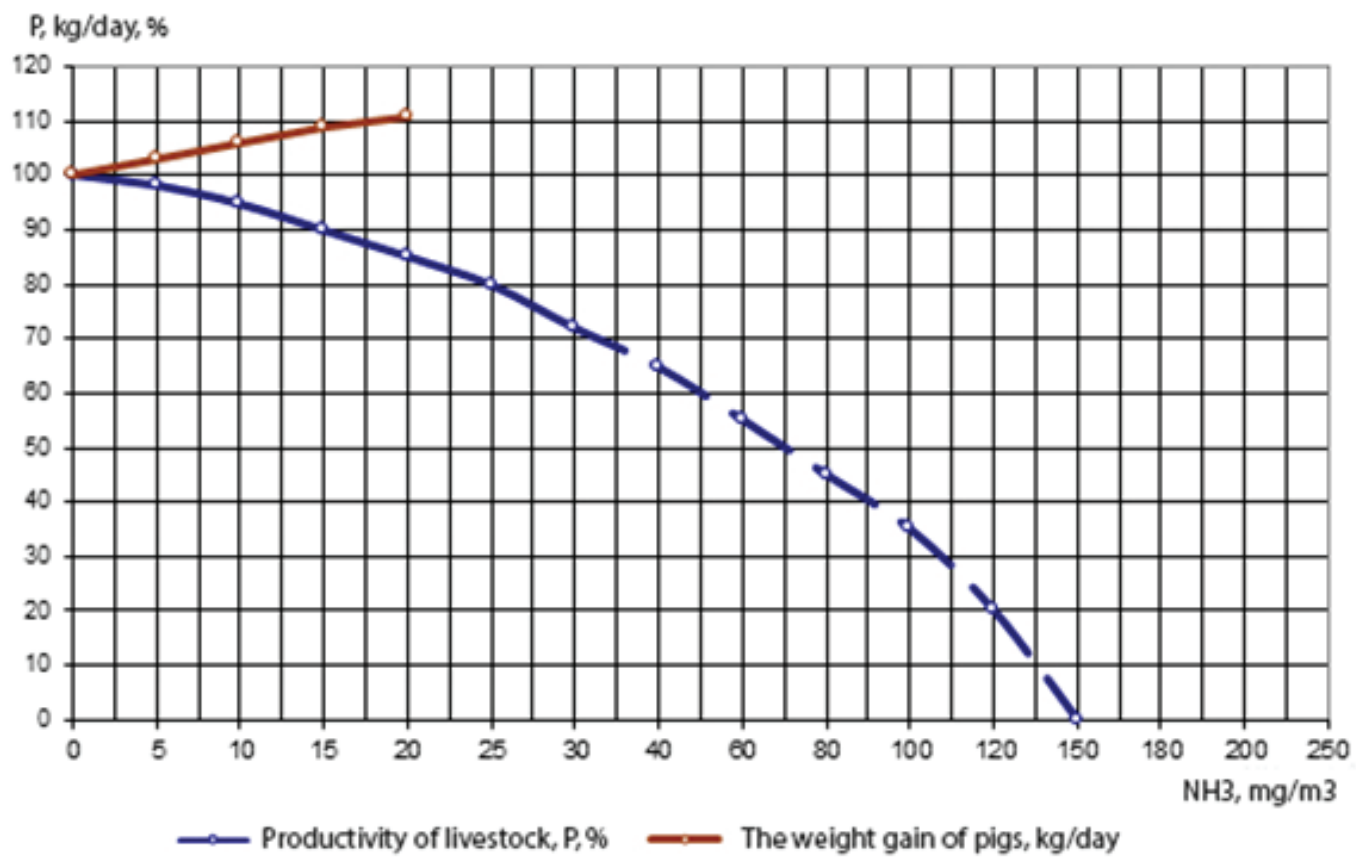

Figure 1: Influence of ammonia concentration in the indoor air of the farm on the pig weight gain and feed consumption

Functional indicators characterize the degree to which the system performs the specified functions, that is, for the microclimate systems, it is the degree to which the normalized parameters of the air environment are provided: its purity, gas composition, temperature, relative humidity, mobility, etc. Quantitative assessment of the required parameters is the initial stage of evaluating the decisions made and directly affects the technological parameters. Technological indicators are the values of heat, cold, air and water consumed for humidification and purification, and chemicals for air purification from harmful gases that are necessary for the systems to perform the specified functions. Since technological indicators are adequate to the functional parameters that characterize the law of system functioning, they are combined into one group.

The group of design and layout indicators includes various types of material costs: material consumption, occupied construction space, ease of installation. 
Operational and energy indicators include the energy assessment of the system, operating conditions, information about energy consumption (it can be expressed as an energy efficiency coefficient).

Economic indicators express all the previous ones in money terms. In general, they are represented as capital, operating and reduced costs.

It should be noted that, as a rule, "environmental" indicators are not taken into account in technological decisions.

Therefore, it is necessary to introduce the fifth group of indicators - environmental.

\section{Conclusions}

The EU countries are implementing a long-term program for the development of environmentally-friendly agriculture, including pig farming. This program has five strategic directions:

1. Protection of livestock and people from the harmful effects of the farm's microclimate and the environment;

In this direction, the authors of the article draw the following conclusions:

1.1. The existing model systems forming the microclimate of livestock farms is based on the control of the temperature and humidity ratio of the air in the premises up to 3...5 times/hour, so the coefficient of efficiency of the heat of the farm indoor air in winter does not exceed 25...30\%, while the harmful gases (ammonia, carbon dioxide, hydrogen sulfide), dust and microbial bodies are released into the environment;

1.2. To explore energy-saving, economic and environmental technologies of formation of parameters of a microclimate of pig farms, it was reviewed and summarized research results in this field and it was developed a mathematical model allowing to obtain analytical dependencies between the feed consumption (energy), the productivity of pigs and the concentration of a harmful gas (ammonia), which is one of the main microclimate parameters.

2. Development of environmentally-friendly production of outputs and measures that promote such production;

3. Development and improvement of equipment for waste disposal and cleaning of livestock emissions;

4. Development of regulatory documents on environmental protection;

5. Reducing product losses during transportation. 


\section{References}

[1] Samarin, G. N. (2008). Habitat Management of Farm Animals and Birds: Monograph. Velikie Luki: FGOU VPO Velikolukskaya State Agricultural Academy.

[2] Samarin, G. N., et al. (2018). Optimization of Microclimate Parameters Inside Livestock. Buildings. Intelligent Computing \& Optimization (Advances in Intelligent Systems and Computing) (vol. 866). Cham: Springer.

[3] Novitsky, I. (2016). Industrial Pig Breeding and the Environment. Agricultural Portal. Pig Breeding, vol. 1 pp. 14-31

[4] Aguirre-Villegas, H. A. and Larson, R. A. (2017). Evaluating Greenhouse Gas Emissions from Dairy Manure Management Practices using Survey Data and Lifecycle Tools. Journal of Cleaner Production, vol. 143, pp. 169-179.

[5] Cobuloglu, H. I. and Bueyuektahtakin, I. E. (2015). Food vs. Biofuel: An Optimization Approach to the Spatio-Temporal Analysis of Land-Use Competition and Environmental Impacts. Applied Energy, vol. 140, pp. 418-434.

[6] Divyalakshmi, D., et al. (2017). Assessment of Microclimate and Gaseous Pollutants in Dairy and Pig Sheds in an Organized Farm. Indian Journal of Animal Sciences, vol. 87, issue 6, pp. 93-96.

[7] Frutos, O. D., et al. (2015). Simultaneous Biological Nitrous Oxide Abatement and Wastewater Treatment in a Denitrifying Off-Gas Bioscrubber. Chemical Engineering Journal, vol. 288, pp. 28-37.

[8] Kaufmann, T. (2015). Sustainable Livestock Production: Low Emission Farm. The Innovative Combination of Nutrient, Emission and Waste Management with Special Emphasis on Chinese Pig Production. Animal Nutrition, vol. 1, issue 3, pp. 104-112.

[9] Liu, F., et al. (2017). Bioscrubber Treatment of Exhaust Air from Intensive Pig Production: Case Study in Northern Germany at Mild Climate Condition. Engineering in Life Sciences, vol. 17, issue 4, pp. 458-466.

[10] Loyon, L., et al. (2016). Best Available Technology for European Livestock Farms: Availability, Effectiveness and Uptake. Journal of Environmental Management, vol. 166, pp. 1-11

[11] Loyon, L., et al. (2016). Assessment of $\mathrm{NH}_{3}$ reduction and $\mathrm{N}_{2} \mathrm{O}$ Production during Treatment of Exhausted Air from Fattening Pigs Building by a Commercial Scrubber. Agricultural Sciences, vol. 7, issue 10, pp. 693-709.

[12] Purdy, A., et al. (2018). Towards Sustainable Farming: Feasibility Study into Energy Recovery from Bio-Waste on a Small-Scale Dairy Farm. Journal of Cleaner Production, vol. 174, pp. 899-904. 
[13] Lewis, N. S., et al. (2016). The Global Antigenic Diversity of Swine Influenza A Viruses Group. Elife, vol. 5, p. e12217

[14] Wenke, C., et al. (2018). Impact of Different Supply Air and Recirculating Air Filtration Systems on Stable Climate, Animal Health, and Performance of Fattening Pigs in a Commercial Pig Farm. Plos One, vol. 13, p. 3.

[15] Zakharov, A. A. (1986). Application of Heat in Agriculture. Moscow: Agropromizdat.

[16] Prokopenko, A. A. (1997). Scientific Justification and Development of Technology for the use of Optical Radiation to Combat Harmful Aerosols in Industrial Poultry Farming. (Dissertation for a Doctorate in Veterinary Sciences, All-Russian Research Institute of Veterinary Sanitation, Hygiene and Ecology, 1997).

[17] Georgievsky, V. I. (1990). Physiology of Farm Animals. Moscow: Agropromizdat.

[18] Onegov, A. P., Hrabutovskij, I. F. and CHernyh, V. I. (1984). Hygiene of Farm Animals. Moscow: Kolos.

[19] Afanasiev, V. N., et al. (2005). Practical Guide for Agricultural Enterprises on Environmental Protection. St. Petersburg: NWNIIMESH.

[20] Bava, L., et al. (2017). Environmental Impact of the Typical Heavy Pig Production in Italy. Journal of Cleaner Production, vol. 140, pp. 685-691.

[21] Calsamiglia, S., et al. (2018). A Stochastic Dynamic Model of a Dairy Farm to Evaluate the Technical and Economic Performance under Different Scenarios. Journal of Dairy Science, vol. 101, issue 8, pp. 7517-7530.

[22] Cowley, F. C., et al. (2015). Immediate and Residual Effects of Heat Stress and Restricted Intake on Milk Protein and Casein Composition and Energy Metabolism. Journal of Dairy Science, vol. 98, issue 4, pp. 2356-2368.

[23] Das, R., et al. (2016). Impact of Heat Stress on Health and Performance of Dairy Animals: A Review. Veterinary World, vol. 9, issue 3, pp. 260-268.

[24] Dumont, E. (2018). Impact of the Treatment of NH3 Emissions from Pig Farms on Greenhouse Gas Emissions. Quantitative Assessment from the Literature Data. NEW Biotechnology, vol. 46, pp. 31-37.

[25] Ferreira, J. B., et al. (2018). Influence of Microclimate Conditions on the Cumulative Exposure of Nursery Pigs to Swine Influenza A Viruses. Transboundary and Emerging Diseases, vol. 65, issue 1, pp. e145-e154.

[26] Gernand, E., Konig, S. and Kipp, C. (2019). Influence of On-Farm Measurements for Heat Stress Indicators on Dairy Cow Productivity, Female Fertility, and Health. Journal of Dairy Science, vol. 102, issue 7, pp. 6660-6671. 
[27] Kino, E., et al. (2019). Exploration of Factors Determining Milk Production by Holstein Cows Raised on a Dairy Farm in a Temperate Climate Area. Tropical Animal Health and Production, vol. 51, issue 3, pp. 529-536.

[28] Mellado, M., et al. (2016). Climatic Conditions, Twining and Frequency of Milking as Factors Affecting the Risk of Fetal Losses in High-Yielding Holstein Cows in a Hot Environment. Tropical Animal Health and Production, vol. 48, issue 6, pp. 1247-1252. 